Article

\title{
Contamination of Detained Sediment in Sustainable Urban Drainage Systems
}

\author{
Deonie Allen*, Heather Haynes and Scott Arthur \\ Water Academy, Heriot-Watt University, Edinburgh, EH144AS, UK; h.haynes@hw.ac.uk (H.H.); \\ s.arthur@hw.ac.uk (S.A.) \\ * Correspondence: d.allen@hw.ac.uk; Tel.: +44-0131-451-8360 \\ Academic Editor: Thilo Hofmann \\ Received: 24 March 2017; Accepted: 16 May 2017; Published: 18 May 2017
}

\begin{abstract}
Adsorption is a key water pollution remediation measure used to achieve stormwater quality improvement in Sustainable urban Drainage Systems (SuDS). The level of contamination of detained sediment within SuDS assets is not well documented, with published investigations limited to specific contaminant occurrence in ponds, wetlands or infiltration devices (bioretention cells) and generally focused on solute or suspended sediment. Guidance on contamination threshold levels and potential deposited sediment contamination information is not included in current UK SuDS design or maintenance guidance, primarily due to a lack of evidence and understanding. There is a need to understand possible deposited sediment contamination levels in SuDS, specifically in relation to sediment removal maintenance activities and potential impact on receiving waterways of conveyed sediment. Thus, the objective of the research presented herein was to identify what major elements and trace metals were observable in (the investigated) SuDS assets detained sediment, the concentration of these major elements and trace metals and whether they met/surpassed ecotoxicity or contaminated land thresholds. The research presented here provides evidence of investigated SuDS sediment major element and trace metal levels to help inform guidance and maintenance needs, and presents a new methodology to identify the general cause (anthropocentric land use) and extent of detained SuDS fine urban sediment contamination through use of a contamination matrix.
\end{abstract}

Keywords: contamination factor; geoaccumulation index; sediment contamination; SuDS; urban contamination

\section{Introduction}

Sustainable urban Drainage Systems (SuDS) within the UK were initially promoted for their water quality treatment or improvement benefits [1]. However, analysis of SuDS contaminant treatment capacities have generally been restricted to surface water quality testing rather than analysis of deposited sediment contaminant concentrations. Literature evidence has been published on water quality assessment for wetlands, swales, linear wetlands (impermeable lined bioswale) and ponds; and tested in case studies located from Portland (USA), to Melbourne (Australia), to the UK. Typically data in the literature focus on surface water quality (including Total Suspended Sediment (TSS)) which influences current guidelines on contaminant treatment efficiency, such as the Construction Industry Research and Information Association of the UK (CIRIA, www.ciria.org) SuDS Manual [1], or the WSUD (Water Sensitive Urban Design) design guidelines from Water by Design [2]. In line with TSS removal, SuDS assets are expected to provide notable heavy metal, mineral and chemical contaminant removal or treatment. Yet current published data and guidance are limited in their evidence of the contamination and treatment of bed deposited sediment within SuDS. Based on traditional design assumptions of long-term sediment detention, the surface-water focus may be deemed justified, as only the surface runoff discharge was assumed to affect downstream watercourses, while sediment was 
expected to remain detained within SuDS assets. However, given the evidence of ongoing sediment movement within SuDS [3,4], this now appears an oversimplification of SuDS conveyance, in that the transport and discharge of sediment must also be fully assessed for its contaminant concentrations and potential impact on downstream watercourses.

It is widely accepted that the majority of urban heavy metal pollution is transported from urban surfaces into the receiving waterways adsorbed to fine sediment $(>80 \%)$ [5]. Whilst contaminants can move easily from solute to adsorbed form, subsequent release of adsorbed contaminants back into suspension is a more complex process, influenced by $\mathrm{pH}$, exchange potential and assisted by catalysts [6-8]. The effectiveness of phytoremediation, a key contaminant treatment process in SuDS, is dependent on the bioavailability of the contaminant, how strongly it is adsorbed to sediment and its' potential to return to solute form for uptake/removal/modification by the plants. Where bioavailability is limited, the availability of solute contaminants is greater than the bioremediation capacity, or where adsorption is the primary remediation process within the SuDS asset, the detained sediment has the potential to become enriched. Significant sediment contaminant enrichment may result in detained sediment illustrating contaminant concentrations above ecotoxicity or contaminated land thresholds, thus classifying the sediment as contaminated.

Elevated levels of sediment contamination (e.g., high heavy metal concentrations on fine sediment) are known to cause ecotoxicity and degradation of water quality, ecosystem services and biodiversity [9]. Contaminated sediment can result in both direct and indirect impacts on the receiving waterways' aquatic ecosystem. In a review undertaken by Fleeger et al. [10], published field studies illustrated river deposited contaminated sediment to directly impact species diversity and abundance in conjunction ecosystem functions such as nutrient cycling and decomposition. For example, copper sediment contamination has been reported to directly influence zooplankton, protozoa and phytoplankton abundance while indirectly influencing bacterial abundance [11,12]. Similarly general heavy metal contamination of sediment (from highway runoff) has been illustrated to cause a direct impact on microbial flood abundance and indirect impact on amphipod feeding [13]. Thus, there is a need to understand if sediment discharged from SuDS assets into receiving waterways is contaminated to identify the potential benefits and risks resultant from urban sediment detention and conveyance through SuDS assets on the receiving waterway ecosystem function and health.

Sediment build-up is expected to occur in SuDS systems, limiting the quantity of urban sediment contaminants reaching downstream receiving waterways. When sediment build-up reaches a level that compromises flood risk or flow conveyance (e.g., 25\% volume loss [14]) the SuDS asset requires maintenance to remove this deposition. If these levels surpass specified threshold conditions, any movement, oxidation or management of this sediment requires compliance with contaminated land protocol (Environmental Protection Act 1990, Part IIA, [15,16]). Therefore, knowledge of the potential contamination levels of detained sediment is vital in defining the maintenance strategy for these assets.

The research presented here aims to provide a more detailed account of SuDS deposited sediment contamination by (i) identifying the sediment contaminant levels within SuDS assets and thus the risk of sediment contamination specific to individual (investigated) SuDS assets; and (ii) examining the spatial variation in contaminant concentration to identify deposition hot spots (localized areas of high contaminant concentration), in order to provide insight into potential sediment enrichment. 


\section{Materials and Methods}

Four common SuDS assets, located in urban development areas within Scotland and northern England, were monitored over an extended period to identify the urban contaminant concentrations of deposited urban sediment (Table 1). Established wetland, linear wetland, swale and pond SuDS assets were monitored fortnightly over a 12-month period (with exception of the pond where access resulted in a 6-month dataset) to identify the fine sediment contaminant concentrations of deposited sediment at multiple locations within each of the SuDS assets.

Table 1. Summary of monitored SuDS asset.

\begin{tabular}{ccccccc}
\hline SuDS Asset & $\begin{array}{c}\text { Surface } \\
\text { Area }\left(\mathbf{m}^{\mathbf{2}}\right)\end{array}$ & $\begin{array}{c}\text { Flow Path } \\
\text { Length }(\mathbf{m})\end{array}$ & $\begin{array}{c}\text { Number of } \\
\text { Sampling } \\
\text { Locations }\end{array}$ & $\begin{array}{c}\text { Flow } \\
\text { Characteristics }\end{array}$ & $\begin{array}{c}\text { Contributing } \\
\text { Catchment } \\
\text { Land Use }\end{array}$ & $\begin{array}{c}\text { Contributing } \\
\text { Catchment } \\
\text { Impervious Area }\end{array}$ \\
\hline $\begin{array}{c}\text { wetland } \\
\text { linear wetland }\end{array}$ & 610 & 110 & 4 & perennial & Commercial & $0.20 \mathrm{~km}^{2}$ \\
short swale & 18 & 220 & 3 & perennial & Commercial & $0.21 \mathrm{~km}^{2}$ \\
long swale & 6 & 150 & 2 & ephemeral & Road & $0.02 \mathrm{~km}^{2}$ \\
pond & 18 & 530 & 2 & ephemeral & Commercial & $0.44 \mathrm{~km}^{2}$ \\
\hline
\end{tabular}

The majority of urban contaminants $(\sim 80 \%)$ are conveyed adsorbed to fine sediment $(<2 \mathrm{~mm})$ [5], and the majority of urban sediment falls within the size classification of clay-sand (d50 $<2 \mathrm{~mm}$ ) [17-19]. To monitor and sample sediment deposited within the established SuDS, sediment traps were installed in the bed of the SuDS assets. Sediment traps were designed to detain sediment up to a $\mathrm{d}_{50}$ of $2 \mathrm{~mm}$ using Van Rjin [20] saltation assessment. The traps were inserted within the bed of the SuDS assets so that no part of the trap protruded above the SuDS bed surface (to avoid disturbance of active transport processes). Sediment traps comprised two containers, an outer box permanently anchored into the bed, remaining in place for the total sampling period (to minimise disturbance during sampling) and an inner (sediment trap) box which was removable for sampling of collected deposits (similar to design used by Lawler [21], IAEA [22] and Fraley [23]).

Sediment samples were collected fortnightly over a 12-month period (with exception of the pond). All sediment samples were analysed for total deposition, major elements and trace metals concentration and particle size distribution. The total deposited was calculated by weight, representative of the bed surface area of collection. Deposited sediment material was collected from the bed traps, dried for 4 days at $105{ }^{\circ} \mathrm{C}$ then weighed. This provided total deposited sediment relative to the sediment trap surface area $\left(0.06 \mathrm{~m}^{2}\right)$ for the monitoring period, i.e., $\mathrm{kg} / \mathrm{m}^{2} /$ fortnight.

A standard array of 15 major elements and trace metals assessable by Inductively Coupled Plasma Optical Emission Spectrometer (ICP-OES) were tested; K, Pb, Fe, Cd, Cr, Mn, Mg, Al, Zn, Ca, Na, Ba, $\mathrm{Cu}, \mathrm{Ni}, \mathrm{Sn}$. Sample preparation followed the seven-stage standard $\mathrm{HNO}_{3}-\mathrm{H}_{2} \mathrm{O}_{2}$ acid digestion method (EPA method 3050B) [24] (also outlined in BS ISO 13547-2:2014 and used by Hseu [25]). ICP OES was also used to quantify the total $P$ nutrient concentrations within each sample. All samples were tested in triplicate. Both sediment deposited within the investigated SuDS assets and background field soil samples were analysed, providing locally specific background soil major element and trace mental concentrations. Results were provided in part per millions (as appropriate to the quantity identified). As part of this procedure, the ICP OES sample analysis calibration confidence and tolerance intervals are provided in Table 2 and standard calibration (against benchmark calibration solutions) prior to sampling was performed by the Scottish Universities Environmental Research Centre (SUREC). 
Table 2. ICP-OES analytes confidence and tolerance intervals. Data provided via academic related technical services standards for the SUERC ICP-OES facility used in this thesis. All values are in parts per million (ppm). The ICP-OES was calibrated for pollutant concentrations of $0.1 \mathrm{ppm}$ to $10 \mathrm{ppm}$.

\begin{tabular}{ccccc}
\hline Analyte & $\begin{array}{c}\text { Study Result } \\
\text { Range (Min-Max) }\end{array}$ & $\begin{array}{c}\text { Consensus Value } \\
\text { (Calibration) }\end{array}$ & $\begin{array}{c}\text { Consensus Value } \\
\text { Confidence Interval }\end{array}$ & $\begin{array}{c}\text { Consensus Value } \\
\text { Tolerance Interval }\end{array}$ \\
\hline $\mathrm{K}$ & $0.1-3.1$ & 3.19 & $3.13-3.25$ & $2.76-3.63$ \\
$\mathrm{~Pb}$ & $0.1-10.8$ & 0.112 & $0.111-0.113$ & $0.101-0.0123$ \\
$\mathrm{Fe}$ & $0.1-1.7$ & 1.29 & $1.27-1.30$ & $1.17-1.41$ \\
$\mathrm{Cd}$ & $0.2-2.16$ & 0.224 & $0.221-0.226$ & $0.203-0.244$ \\
$\mathrm{Cr}$ & $0.1-9.80$ & 0.437 & $0.432-0.443$ & $0.394-0.481$ \\
$\mathrm{Mn}$ & $0.1-2.0$ & 0.345 & $0.342-0.349$ & $0.318-0.373$ \\
$\mathrm{Mg}$ & $0.1-2.0$ & 6.92 & $6.83-7.00$ & $6.31-7.52$ \\
$\mathrm{Al}$ & $0.1-2.4$ & 0.233 & $0.29-0.238$ & $0.199-0.268$ \\
$\mathrm{Zn}$ & $0.1-2.3$ & 0.881 & $0.781-0.891$ & $0.809-0.954$ \\
$\mathrm{Ca}$ & $0.1-1.9$ & 7.69 & $7.59-7.79$ & $7.00-8.38$ \\
$\mathrm{Na}$ & $0.1-2.4$ & 19.1 & $18.9-19.3$ & $17.4-20.8$ \\
$\mathrm{Ba}$ & $0.2-1.6$ & 3.35 & $1.72-1.77$ & $1.55-1.94$ \\
$\mathrm{Cu}$ & $0.3-2.6$ & 0.844 & $0.833-0.856$ & $0.757-0.931$ \\
$\mathrm{Ni}$ & $0.1-6.1$ & 0.840 & $0.830-0.849$ & $0.767-0.912$ \\
$\mathrm{Sn}$ & $0.3-5.7$ & 0.916 & $0.897-0.934$ & $0.789-1.043$ \\
$\mathrm{P}$ & $0.1-3.0$ & 0.495 & $0.485-0.505$ & $0.432-0.557$ \\
\hline
\end{tabular}

Particle size distribution (PSD) analysis was undertaken for all samples to identify the modal characteristics. While it is acknowledged that urban sediment (fine sand to clay material) has cohesive properties and thus can form cohesive particulates, the focus of this research was not extended to delineation between cohesive and non-cohesive particle size analysis nor the PSD analysis of compound (cohesive) particulates. As such, the particle size analysis was undertaken following standard practice and therefore provided dispersed PSD results for field samples.

PSD testing was undertaken using two methods; sieving and laser diffraction. Field samples were dried at $105^{\circ} \mathrm{C}$ for $24 \mathrm{~h}$. Dried sample material was then manually sieved. In line with the objectives of this research fractions, $\leq 2 \mathrm{~mm}$ were retained for analysis using the laser diffraction method of the Mastersizer S (long bench configuration) (analysis of $4.2 \mu \mathrm{m}$ up to $2000 \mu \mathrm{m}$ ). For this latter method, fines were re-suspended in deionised water via shaking for up to $5 \mathrm{~min}$. The suspended sediment sample was added to the sample pump ( 1500 rpm) and passed through a laser beam where detectors placed at fixed angles measured the intensity of light scattered at that position. A mathematical model (i.e., Mie/Fraunhoffer Theory) was then applied to generate a particle size distribution [26,27]. The final result was reported on an Equivalent Spherical Diameter Volume basis. All samples were tested in triplicate, and provided results within the acceptable variance of $\pm 5 \%$. The sample (uni) modal particle size was recorded for each sample.

Field collected sediment major elements and trace metal concentrations were then compared to literature published ecotoxicity and contamination thresholds. Field results were directly compared to literature threshold levels to identify if the investigated SuDS assets illustrated potential ecotoxicity or contaminated sediment levels. It should be noted that adsorption is a fundamental remediation process within SuDS assets and these elevated levels of major elements and trace metals on detained sediment show SuDS functionality (beneficial to solute water quality). Further analysis was undertaken to create a SuDS sediment contamination matrix, aimed to advance understanding of the levels, generic causes and location of (the investigated) SuDS asset sediment contamination. To create this matrix the field sediment sample results were compared to background soil concentrations to identify enrichment of SuDS sediment by major elements and trace metals. This was combined with Geoaccumulation Index analysis of field samples to provide an indication of the scale or level of contamination occurring. The resultant matrix is presented for the investigated SuDS assets. It is acknowledged that the antecedent conditions for each of the investigated SuDS assets may vary (due to location, contributing catchment, duration of function, maintenance, etc.); and thus, direct comparison of the assets can only 
occur with the assumption of relative impact due to antecedent conditions and/or acceptance of this source of result uncertainty.

\section{Results}

\subsection{Deposited Sediment contAminant Concentrations}

The contaminant concentrations of bed deposited sediment samples were analysed and compared to the contaminated land and ecotoxicity thresholds (presented in Table 3). The comparison was undertaken to provide context to the contaminant levels within the different monitored SuDS assets. The contaminant concentrations of deposited sediment for each of the monitored assets are presented (Figure 1) to identify the level of contamination relative to literature published thresholds. Figure 1 presents the existing contaminant levels and thus the risk of contamination in individual SuDS assets without specifically considering the reason or cause of differences in contaminant concentrations.

Field collected sediment contamination results were compared to published contaminant threshold levels (red: contamination trigger exceedance; blue: ecotoxicity trigger exceedance within Figure 1). Key published contaminant contamination levels are presented in Table 3. Guideline and threshold values chosen for further field data set analysis were selected by relative proximity to the field sample sites (UK), placing priority on use of the UK ICRCL information followed by EU information.

Table 3. Summary of published contaminant threshold levels.

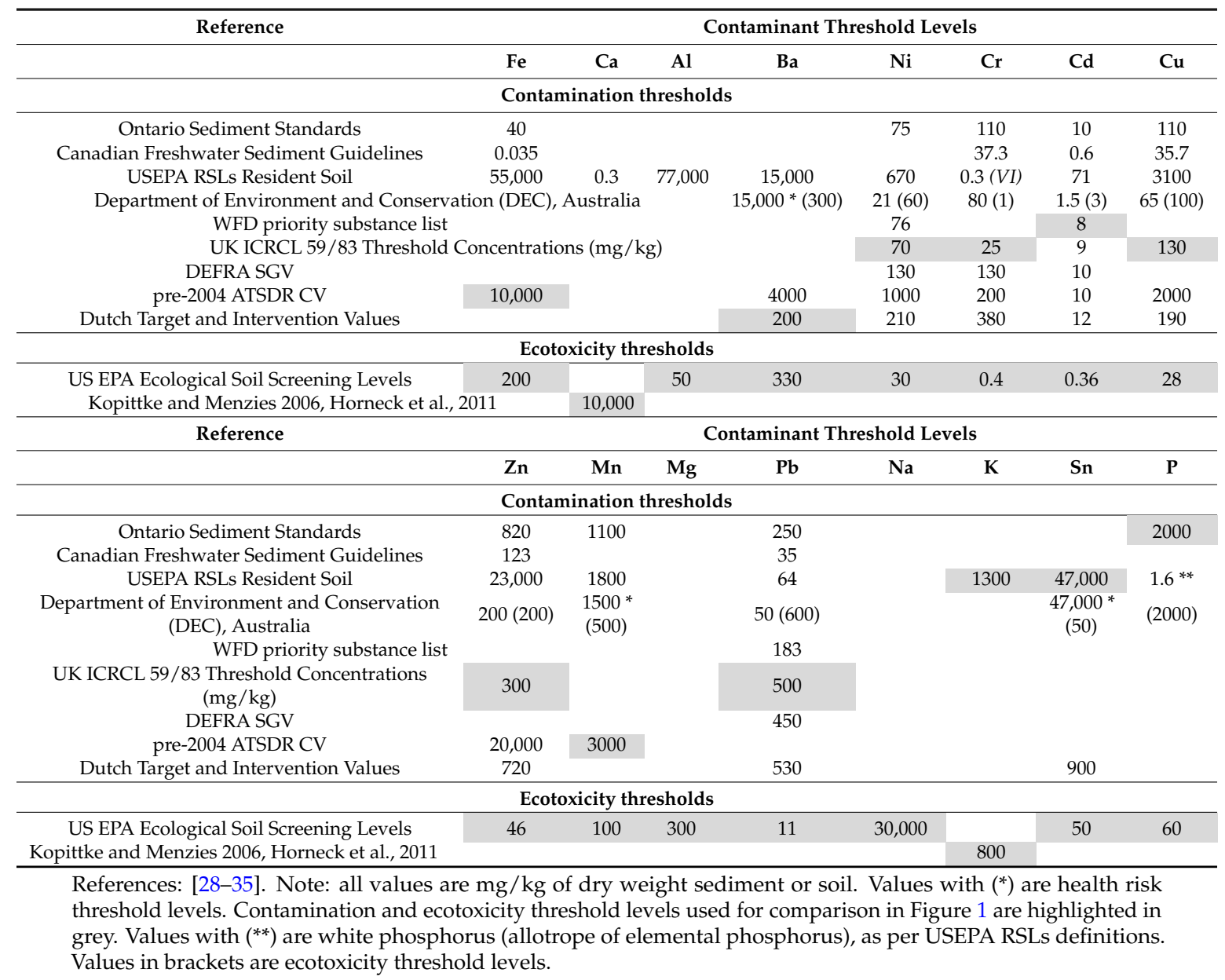

Table 3 illustrates that not all guidelines consider the same contaminants, and that threshold levels vary between authorities and guidance documents. The UK guidelines provide threshold levels for $\mathrm{Ni}, \mathrm{Cr}, \mathrm{Cd}, \mathrm{Cu}, \mathrm{Zn}$ and $\mathrm{Pb}$, and these are similar to published USA/Canada/Australia/NZ guidance 
threshold levels. As the sediment contaminant levels found within SuDS are not frequently described in literature, field sample contaminant results were compared to the contaminated land/ecotoxicity indicators provided in the guidance documents (Table 3).

The deposited sediment contaminant concentrations for the established wetland, linear wetland, swale and pond SuDS assets are illustrated in Figure 1, in conjunction with published threshold levels (detailed in Table 3) to provide context and comparison of contamination levels.
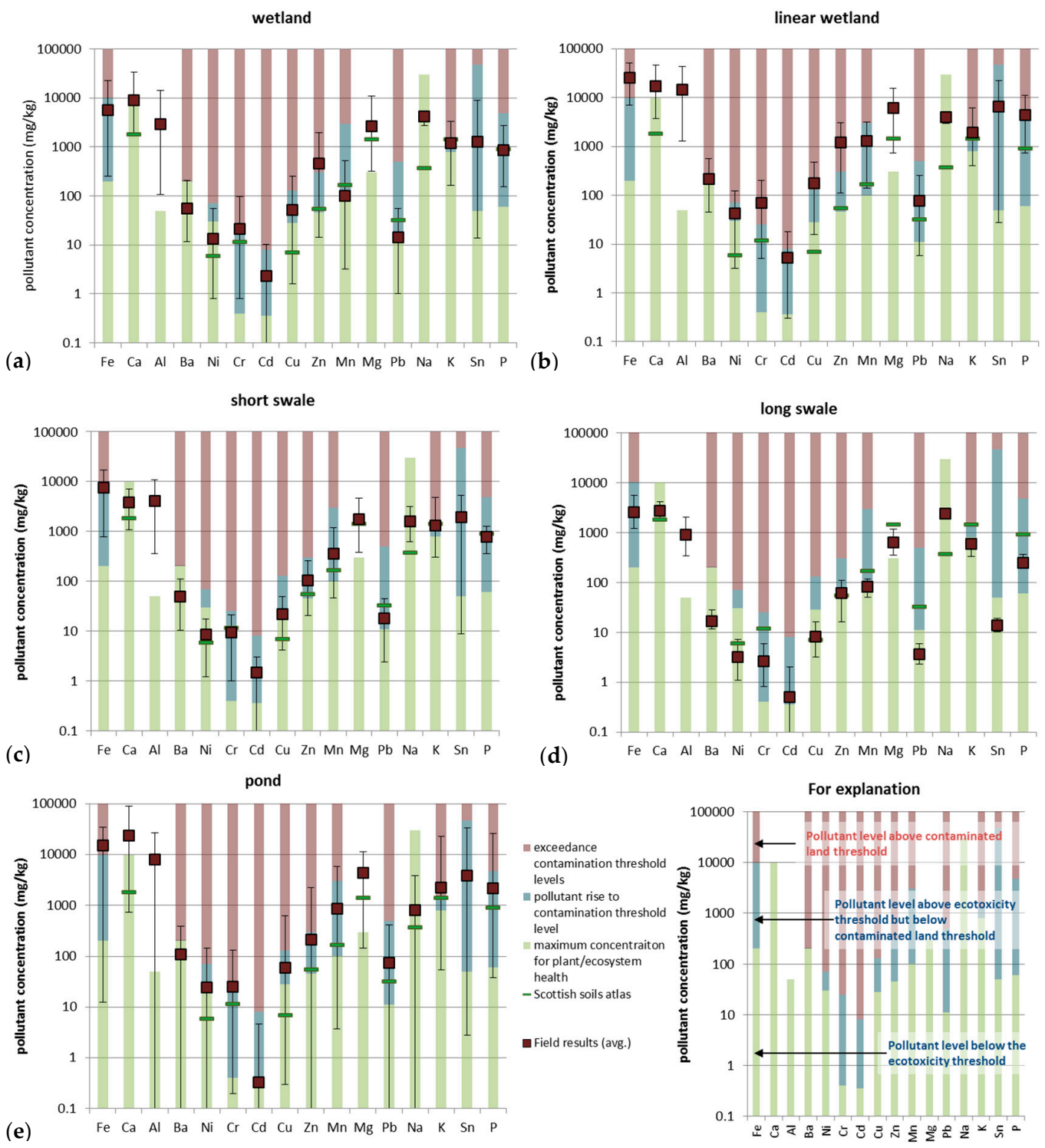

Figure 1. A comparison of deposited sediment contaminant concentrations for the wetland (a), linear wetland (b), short swale (c), long swale (d) and pond (e). Red bars indicated the exceedance of contaminated land thresholds and have no upper limit, blue bars indicate exceedance of ecotoxicity levels and green bars indicate sediment contaminant levels below ecotoxicity thresholds. Where no contaminated land thresholds are presented in guidance documents, the blue and red bars are vacant from the graphs. Field data falling within the red bars indicate exceedance of contaminated land threshold trigger and therefore may be of concern.

The field results show that, with the exception of the long swale, the monitored SuDS sediment contamination levels reach or exceed the contaminated land threshold (for at least one sample and at least one contaminant). This suggests that the adsorption process functioning within SuDS to 
remove solute contaminants from stormwater may be effective, resulting in contaminants becoming temporarily detained through adsorption to urban fine sediment deposited on the SuDS bed.

The average field sample results are generally below the contamination threshold levels, but above ecotoxicity levels. The exception to this is: $\mathrm{Cr}$ and $\mathrm{K}$, where field average values fall at the contamination threshold levels; $\mathrm{Zn}$, where average field results are above contamination threshold levels; and $\mathrm{Ba}, \mathrm{Ni}$ and $\mathrm{Na}$ which show average field values below ecotoxicity levels.

The wetland sediment contaminant levels (Figure 1a) range and average values are generally greater than previously published result (for wetlands) for $\mathrm{Cd}, \mathrm{Zn}$ and $\mathrm{Cu}$ (tyre wear contaminants) (Table 4). This may be due to traffic use in the field sample location or other source related variations between field sites. Field results are at or below published sediment contamination results for $\mathrm{Ni}$ and $\mathrm{Cr}$ (primarily vehicle and motor degradation contaminants).

Table 4. Comparison of published and field wetland contaminant concentrations.

\begin{tabular}{ccccc}
\hline \multirow{2}{*}{ Contaminant } & \multicolumn{2}{c}{ Literature Published [14,36-38] } & \multicolumn{2}{c}{ Field Dataset } \\
\cline { 2 - 5 } & Mean & Range & Mean & Range \\
\hline $\mathrm{Cd}$ & 0.42 & $0.3-2.54$ & 2.34 & $0.1-10.4$ \\
$\mathrm{Zn}$ & 80.46 & $42.2-2580$ & 458.08 & $14.2-1982$ \\
$\mathrm{Cu}$ & 7.54 & $4.58-46.8$ & 51.86 & $1.6-254.1$ \\
$\mathrm{Ni}$ & 76.74 & $7.72-208$ & 13.58 & $0.8-54.7$ \\
$\mathrm{Cr}$ & 26.64 & $9.47-402$ & 21.32 & $0.8-97.3$ \\
\hline
\end{tabular}

Note: literature published average are indicative only as they are the mean of multiple pubed datasets that may not be comparative.

The sediment within the investigated linear wetland is found to show a greater variation in contamination, with seven (7) contaminants illustrating average values at or above contamination threshold levels ( $\mathrm{Fe}, \mathrm{Ba}, \mathrm{Cr}, \mathrm{Cu}, \mathrm{Zn}, \mathrm{K}$ and $\mathrm{P}$ ). Only one contaminant, $\mathrm{Na}$, presented average deposited sediment concentrations below ecotoxicity levels, while $\mathrm{Ca}, \mathrm{Ba}, \mathrm{Ni}, \mathrm{Cd}, \mathrm{Cu}, \mathrm{Pb}, \mathrm{K}$ and $\mathrm{Sn}$ show the lower range of results extending below ecotoxicity threshold levels.

The sediment deposited within the investigated short swale (Figure 1c) showed elevated contaminant levels for $\mathrm{K}$, with average sediment contaminant concentrations falling at or close to the contamination threshold level. Fe and $\mathrm{K}$ are the only two contaminants to show an upper range of results within the contamination exceedance range. The majority of contaminants $(\mathrm{Cr}, \mathrm{Cd}, \mathrm{Cu}, \mathrm{Zn}, \mathrm{Mn}$, $\mathrm{Pb}, \mathrm{Zn}, \mathrm{Sn}$ and $\mathrm{P}$ ) illustrate average contaminant levels between ecotoxicity and contamination levels, but it is important to note that $\mathrm{Cr}$ and $\mathrm{P}$ data range lies consistently in breach of ecotoxicity threshold levels. Only $\mathrm{Ca}, \mathrm{Ni}, \mathrm{Na}$ and $\mathrm{Ba}$ average sediment contaminant concentrations fall below ecotoxicity levels. Thus, sediment deposited within the short swale is not generally illustrated to be contaminated, but is above the ideal levels with regards to ecosystem health (within the swale).

The long swale (Figure 1d) does not show any results above contaminated land threshold levels. $\mathrm{Fe}, \mathrm{Cr}, \mathrm{Cd}, \mathrm{Zn}, \mathrm{Mn}, \mathrm{K}$ and $\mathrm{P}$ average contaminant concentrations are above the threshold ecotoxicity levels (but below contamination threshold levels). Of these contaminants, $\mathrm{Fe}, \mathrm{Cr}$ and $\mathrm{P}$ show the lower range of field results to also fall in exceedance of the ecotoxicity threshold levels. This suggests that while these contaminants are not of concern with regards to contaminated land conditions they may influence the long swale ecosystem health. The long swale may show lower contaminant concentration levels on deposited sediment due to the location of the swale. While the short swale receives stormwater directly from impermeable road surface, the long swale runoff is conveyed via an upstream SuDS asset prior to reaching the long swale. Thus, the lower sediment contaminant concentrations in this swale may be due to its placement as 2 nd SuDS asset within a SuDS treatment train.

The pond's results (Figure 1e) show nine major elements and trace metals to have at least one sample with concentration levels above contaminated land threshold levels ( $\mathrm{Fe}, \mathrm{Ba}, \mathrm{Ni}, \mathrm{Cr}, \mathrm{Cu}, \mathrm{Zn}$, $\mathrm{Mn}, \mathrm{K}$ and $\mathrm{P}$ ). Of these, only two contaminants, $\mathrm{Fe}$ and $\mathrm{K}$, show average concentrations above 
contamination threshold levels. Notably all contaminants tested show a wide concentration range suggesting temporal and/or spatial variability in the results.

The pond contamination levels have been compared to those reported by Heal and Drain for a range of UK ponds (Table 5). The pond sediment contamination levels (Figure 1e) for $\mathrm{Cr}$ and $\mathrm{Ni}$ are generally below those presented in Heal and Drain [37], Table 5. However, $\mathrm{Cu}, \mathrm{Cd}, \mathrm{Pb}$, and $\mathrm{Zn}$ sediment contaminant concentrations in the monitored pond are higher than literature reported levels.

Table 5. Comparison of published and field pond contaminant concentrations.

\begin{tabular}{ccccc}
\hline \multirow{2}{*}{ Contaminant } & \multicolumn{2}{c}{ Literature Published [37] } & \multicolumn{2}{c}{ Field Dataset } \\
\cline { 2 - 5 } & Mean & Range & Mean & Range \\
\hline $\mathrm{Cd}$ & 0.07 & $0-1.67$ & 0.35 & $0.1-4.7$ \\
$\mathrm{~Pb}$ & 17 & $6.59-118$ & 74 & $0.1-419$ \\
$\mathrm{Zn}$ & 66 & $15.8-283$ & 216 & $0.1-2225$ \\
$\mathrm{Cu}$ & 15 & $8.06-46.7$ & 60 & $0.3-638$ \\
$\mathrm{Ni}$ & 37 & $10.8-194$ & 25 & $0.1-143$ \\
$\mathrm{Cr}$ & 42 & $7.45-337$ & 24 & $0.2-132$ \\
\hline
\end{tabular}

The wetland, linear wetland, short swale and pond all show some level of deposited sediment contamination (average sediment contaminant concentrations above contamination threshold levels). Table 6 summarises the average sediment contaminant concentrations for each SuDS asset. K is consistently elevated above contaminated threshold levels across these SuDS assets, while elevated levels of Fe are found in the pond, short swale and linear wetland.

Table 6. Summary of average contaminant concentration levels relative to contamination classifications.

\begin{tabular}{|c|c|c|c|}
\hline \multirow{2}{*}{ SuDS Asset } & \multicolumn{3}{|c|}{ List of Contaminants with Average Values Higher than the Listed Threshold Levels } \\
\hline & Contaminated Land & Ecotoxicity & Below All Threshold Levels \\
\hline wetland & $\mathrm{K}, \mathrm{Zn}, \mathrm{Cr}$ & $\mathrm{Cd}, \mathrm{Al}, \mathrm{Mn}, \mathrm{Pb}, \mathrm{Sn}, \mathrm{Mg}, \mathrm{P}, \mathrm{Cu}, \mathrm{Ca}, \mathrm{Fe}$ & $\mathrm{Na}, \mathrm{Ba}, \mathrm{Ni}$ \\
\hline linear wetland & $\mathrm{K}, \mathrm{Fe}, \mathrm{Zn}, \mathrm{Cr}, \mathrm{Ba}, \mathrm{Cu}, \mathrm{P}$ & $\mathrm{Cd}, \mathrm{Al}, \mathrm{Mn}, \mathrm{Pb}, \mathrm{Sn}, \mathrm{Ca}, \mathrm{Ni}$ & $\mathrm{Na}$ \\
\hline short swale & $\mathrm{K}, \mathrm{Fe}$ & $\mathrm{Cd}, \mathrm{Al}, \mathrm{Mn}, \mathrm{Pb}, \mathrm{Sn}, \mathrm{Mg}, \mathrm{P}, \mathrm{Cu}, \mathrm{Cr}, \mathrm{Zn}$, & $\mathrm{Na}, \mathrm{Ba}, \mathrm{Ca}, \mathrm{Ni}$ \\
\hline long swale & - & $\mathrm{Cd}, \mathrm{Al}, \mathrm{Mn}, \mathrm{Mg}, \mathrm{P}, \mathrm{Cr}, \mathrm{Zn}, \mathrm{Fe}, \mathrm{K}$ & $\mathrm{Na}, \mathrm{Ba}, \mathrm{Ca}, \mathrm{Ni}, \mathrm{Cu}, \mathrm{Pb}, \mathrm{Sn}$ \\
\hline pond & $\mathrm{K}, \mathrm{Fe}$ & $\mathrm{Cd}, \mathrm{Al}, \mathrm{Mn}, \mathrm{Pb}, \mathrm{Sn}, \mathrm{Mg}, \mathrm{P}, \mathrm{Cu}, \mathrm{Ca}, \mathrm{Cr}, \mathrm{Zn}, \mathrm{Ni}$ & $\mathrm{Na}, \mathrm{Ba}$ \\
\hline
\end{tabular}

The linear wetland has the greatest number of contaminants (7) illustrating average (mean) concentrations above contaminated land threshold levels. The tabulation of average contaminant concentrations relative to threshold levels suggests a SuDS asset ranking of the linear wetland > wetland > short swale, pond > long swale in the detention (within the deposited sediment) of the number of contaminants above the contaminated land threshold. It also suggests that all the monitored SuDS assets illustrate deposited sediment contaminant levels that may be of concern with regard to ecosystem health (all assets show a minimum of 7 contaminants with concentrations above ecotoxicity threshold levels). Na appears to consistently fall below ecotoxicity threshold levels for all SuDS assets, suggesting that this contaminant is not of concern within any of the monitored SuDS assets.

\subsection{Spatial Contaminant Concentration with SuDS}

The spatial contaminant concentration of deposited sediment within the monitored SuDS assets have been graphically visualised (Figure 2). Although the number of sampling points is limited, this identifies whether the SuDS asset sediment contamination could be generalised, if sediment contaminant trends occur, and if there are hot spots of contamination within the SuDS assets. In conjunction with the graphical representation of sediment contaminant levels, correlation analysis was undertaken to identify the linkage between sediment deposition and particle size distribution of deposited material at each sample location. 


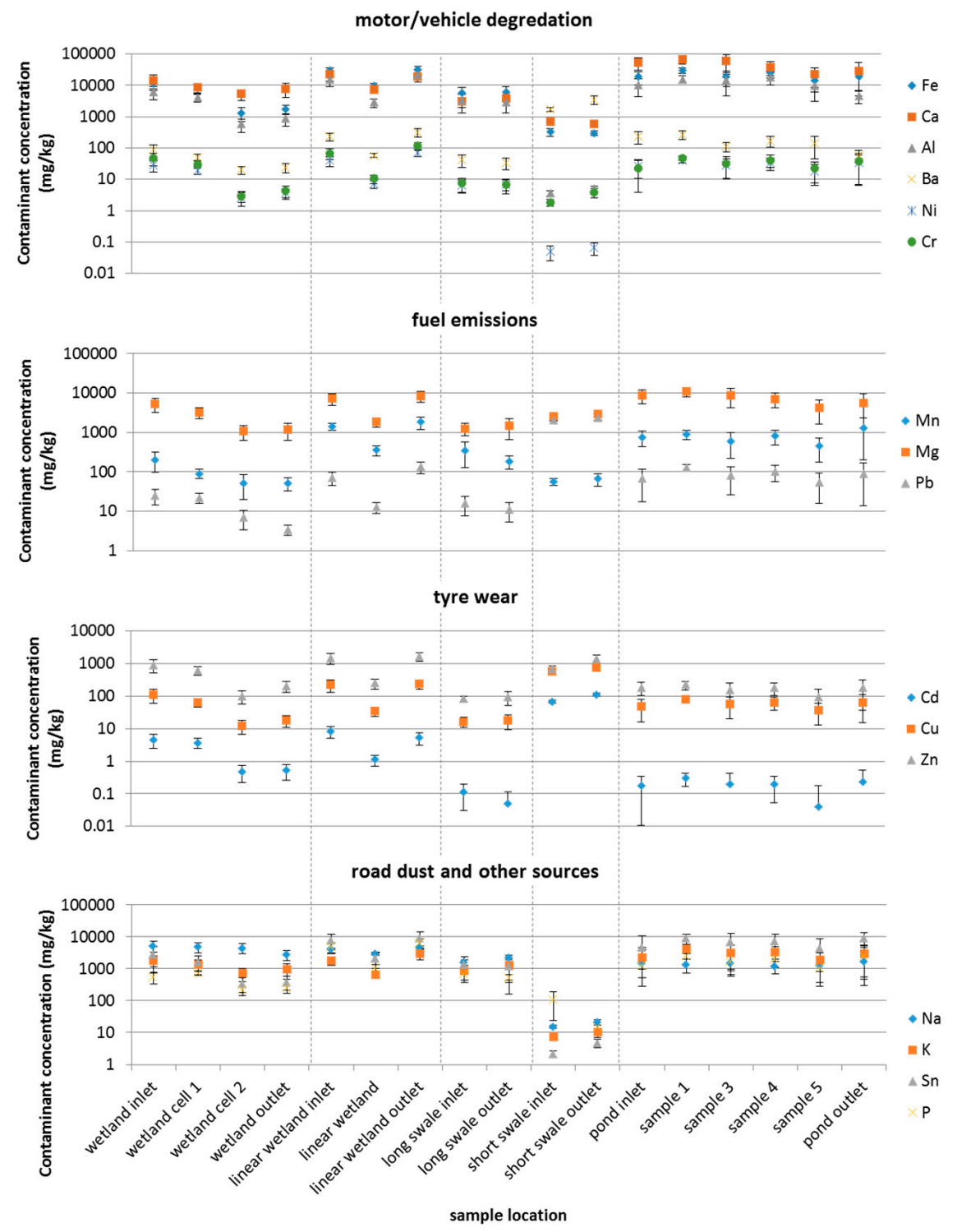

Figure 2. Sediment contaminant concentrations from monitoring points across the SuDS assets. The error bars illustrate sample range for each sample location and contaminant. Sediment contaminants have been presented relative to one of their primary urban sources (e.g., tyre wear) for ease graphical clarity.

Sediment adsorbed contaminant concentrations are found to decline in the wetland and upper-mid section of the linear wetland, but not consistently within the swale or pond. The wetland is the only SuDS asset showing a decrease in sediment contaminant concentration for all contaminants. Both the swales and pond show sediment enrichment for multiple contaminants (also found at the linear wetland outlet). Overall, $\mathrm{K}$ and $\mathrm{Na}$ are found to increase in concentration across all SuDS assets except the wetland, while $\mathrm{Mg}$ becomes enriched in the linear wetland and swales.

Investigated SuDS asset inlet concentration is found to show negligible correlation to the outlet concentration of sediment contaminants in the wetland, linear wetland and pond (perennial assets), but strong correlations with both the long and short swales (ephemeral assets). Thus, ephemeral vs. perennial flow may provide an influence on sediment contaminant enrichment or remediation activities, with the concentration of contaminants at the inlet of perennial assets being of little influence but the concentration at ephemeral SuDS assets being of potential importance and influence on sediment remediation or enrichment. 


\subsection{Sediment Deposition with SuDS}

Bed deposition for each monitored SuDS asset for the relative sample period is presented in Figure 3. The standard deviation of results is indicated by the black lines. Average values and standard deviations are presented to emphasize the asset specific changes and trends in deposited sediment. The sampling frequency for the wetland, linear wetland and swales are fortnightly; while the pond was monthly (due to access constraints). To allow for direct comparison, the approximate fortnightly sediment deposition averages for the pond are presented (grey points, Figure 3).

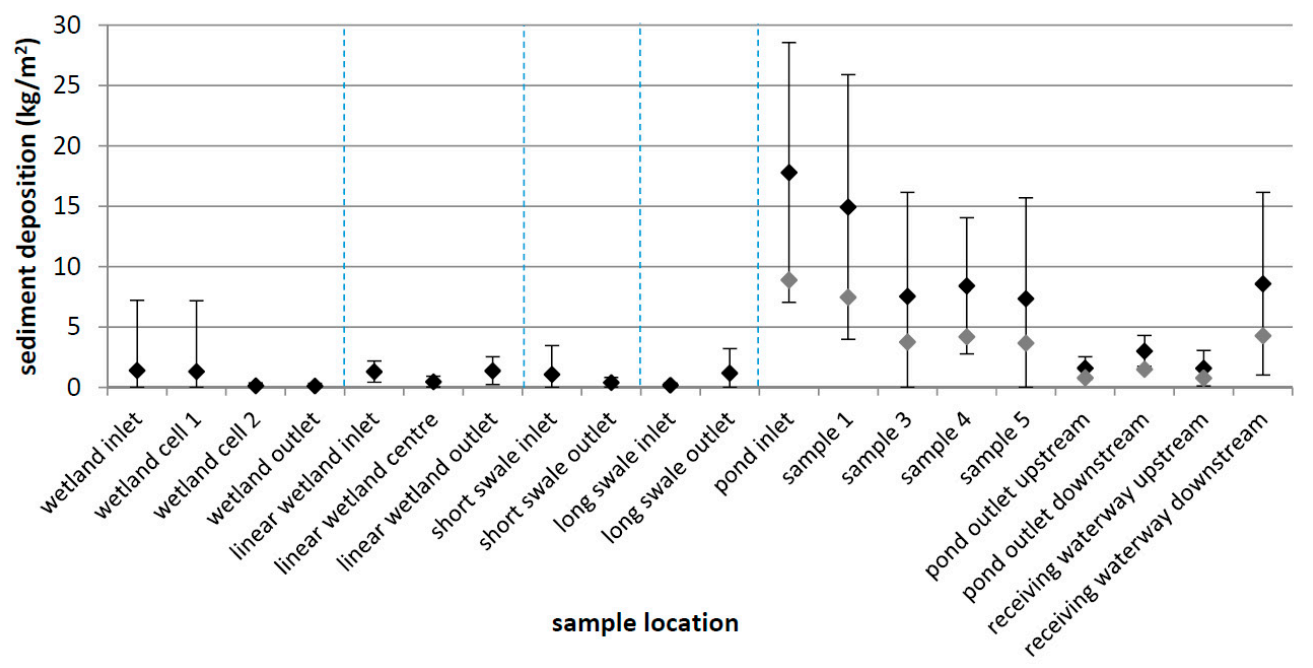

Figure 3. Deposited sediment within the investigated SuDS assets.

The overall investigated SuDS asset deposition data show the linear wetland to achieve the highest average deposition $\left(1.1 \mathrm{~kg} / \mathrm{m}^{2}\right)$. When disaggregated to sample location, the inlet section (inlet and cell 1) of the wetland, short swale inlet and long swale outlet all exhibit deposition rates of approximately $1.3 \mathrm{~kg} / \mathrm{m}^{2} \pm 0.2 \mathrm{~kg} / \mathrm{m}^{2}$. The linear wetland illustrates multiple sample locations above $1.3 \mathrm{~kg} / \mathrm{m}^{2}$ illustrating this asset to be consistent in achieving relative elevated sediment detention. However, it is noted that the upstream half of the wetland has elevated (with large standard deviation) detention results and both swales show an area of elevated detention. The wetland inlet and cell 1 higher deposition results may occur due to the direct supply (surface source) and/or flow dynamics of overland/piped stormwater entering a waterbody (resulting in velocity decrease and deposition potential). Similar influences may result in the short swale inlet elevated sediment detention results. The long swale outlet discharges into a pond/standing waterbody and thus has a wet downstream boundary condition water level. This may reduce flow velocity at the outlet section of this swale and correspondingly result in the elevated sediment detention at this location.

Review of the pond results suggests an overall $1.0-3.2 \mathrm{~kg} / \mathrm{m}^{2}$ bed deposition. Consideration of location specific deposition within the pond suggests a general declining trend along the flow path (both in sample location average and general standard deviation range). The greatest deposition occurs at the inlet, similar to the wetland, suggesting effective general detention design of the pond (i.e., detention is occurring throughout the pond not just in one location, e.g., at the inlet or outlet). However, while detention is illustrated within the pond, receiving waterway results do suggest the potential release of sediment from the pond to impact on downstream water quality. This tentatively suggests that while the pond is functioning as a sink for urban sediment from the upstream development, it may also be acting as a source of sediment to the receiving waterway. The overall asset hierarchy (based on overall deposition) of the investigated SuDS may be pond $>$ linear wetland $>$ wetland short swale > long swale. 


\subsection{Deposited Sediment Modal Particle Size with Investigated SuDS}

In conjunction with deposited sediment contamination concentration analysis and investigated SuDS asset deposition, the modal particle size of deposited sediment was also analysed. The average (and standard deviation) values for each sample location are presented in Figure 4.

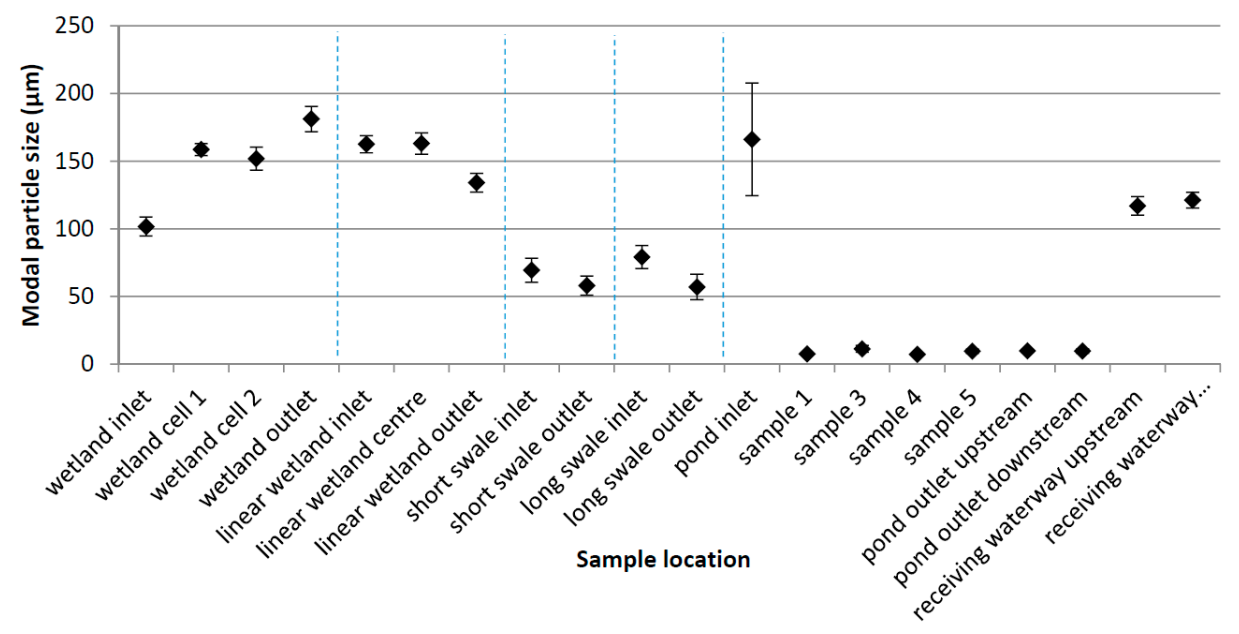

Figure 4. Modal particle size for deposited sediment within the investigated SuDS assets.

All samples illustrated a monodisperse (unimodal) result with a well-defined modal particle size range found within each sample. Within the wetland, bed deposition particle size is found to be finest at the inlet and between 151 and $181 \mu \mathrm{m}$ across the remainder of the wetland. The fine sediment deposition found at the wetland inlet may correlate to higher general deposition (Figure 3) and the turbulent flow supportive of larger sediment (re-) entrainment and suspension. The bed deposition maximum particle size increases up to $300 \mu \mathrm{m}$. This suggests that the fraction below $30 \mu \mathrm{m}$ is mobile and subject to deposition-re-entrainment within and through the wetland asset. In general, the wetland detained a greater quantity of larger $(>100 \mu \mathrm{m})$ sediment particles than smaller ones, effectively shifting the modal particle size and particle size distribution down (towards $0.45 \mu \mathrm{m}$ ). The wetland functions to decrease the overall quantity of larger sediment conveyed downstream, with a lesser impact on the conveyance of fine (clay sized) particles.

Bed deposits in the linear wetland show a distinct gradual inverse relationship between grain size and distance from inlet. The decrease in modal particle size of deposited material in the linear wetland moving downstream is potentially due to (increasing) aggregation of clay and silt (cohesive) particles along the flow path and thus deposition of aggregated cohesive sediment further through the linear wetland. This does suggest that the linear wetland functions as an effective fine sediment filter.

The short and long swale illustrates a decrease in modal particle size between inlet and outlet. The decrease in modal particle size is from an average of 69 to $57 \mu \mathrm{m}$ in the short swale and 79 to $56 \mu \mathrm{m}$ in the long swale. The decrease in modal particle size may be due the efficiency of short vegetation and a shallow flow depth through the swale resulting in effective vegetation filtration of fine sediment. It may also result from cohesive particle aggregation and settling resulting in greater individual particle fine sediment deposition down the swale flow path.

Within the pond, larger modal particle sizes are found deposited adjacent to the pond inlet. The central pond flow path, samples 1-pond outlet upstream, all illustrate notably smaller modal particle sizes (below $40 \mu \mathrm{m}$ ). The pond is highly effective at detaining fine, clay sized, particles. This may be partly due to the higher clay fraction in the supply and the controlled outlet design. 


\subsection{Correlation of Deposited Sediment Contamination Concentration, Modal Particle Size and Depostion Mass}

Contaminant concentration of deposited sediment was correlated to deposited sediment particle size and the quantity of sediment deposited during the monitoring period. Pearson's correlation analysis was completed for each asset, comparing the deposition at each location and modal particle size (Figures 3 and 4) to contaminant concentrations (Figure 2). The correlation results are presented in Table 7, and illustrate the overall correlation results for each asset. It should be noted that all strong correlations illustrated a $p<0.05$.

Table 7. Correlation coefficient results for average contaminant concentrations, sediment deposition and deposited sediment modal particle size for each SuDS asset. Strong correlations are presented in black, minor and moderate correlations and presented in grey.

\begin{tabular}{|c|c|c|c|c|c|c|c|c|c|c|}
\hline \multirow[b]{2}{*}{ Contaminant } & \multicolumn{2}{|c|}{ Wetland } & \multicolumn{2}{|c|}{ Linear Wetland } & \multicolumn{2}{|c|}{ Short Swale } & \multicolumn{2}{|c|}{ Long Swale } & \multicolumn{2}{|c|}{ Pond } \\
\hline & $\begin{array}{c}\text { Sediment } \\
\text { Deposition }\end{array}$ & $\begin{array}{c}\text { Modal } \\
\text { Particle } \\
\text { Size }\end{array}$ & $\begin{array}{c}\text { Sediment } \\
\text { Deposition }\end{array}$ & $\begin{array}{c}\text { Modal } \\
\text { Particle } \\
\text { Size }\end{array}$ & $\begin{array}{c}\text { Sediment } \\
\text { Deposition }\end{array}$ & $\begin{array}{c}\text { Modal } \\
\text { Particle } \\
\text { Size }\end{array}$ & $\begin{array}{l}\text { Sediment } \\
\text { Deposition }\end{array}$ & $\begin{array}{c}\text { Modal } \\
\text { Particle } \\
\text { Size }\end{array}$ & $\begin{array}{c}\text { Sediment } \\
\text { Deposition }\end{array}$ & $\begin{array}{c}\text { Modal } \\
\text { Particle } \\
\text { Size }\end{array}$ \\
\hline $\mathrm{Ca}$ & 0.8 & -0.8 & 0.9 & -0.4 & 0.4 & 0.4 & -0.4 & 0.2 & 0.5 & 0.8 \\
\hline $\mathrm{Al}$ & 0.9 & -0.8 & 0.9 & -0.8 & -0.8 & -0.9 & 0.0 & -0.7 & 0.0 & 0.5 \\
\hline $\mathrm{Ba}$ & 0.9 & -0.9 & 0.9 & -0.8 & -0.7 & -0.9 & -0.1 & -0.6 & 0.5 & 0.9 \\
\hline $\mathrm{Ni}$ & 0.9 & -0.8 & 0.9 & -0.9 & -0.7 & -0.9 & 0.0 & -0.6 & -0.2 & 0.4 \\
\hline $\mathrm{Cu}$ & 0.9 & -0.8 & 0.9 & -0.6 & -0.9 & -0.9 & -0.2 & -0.5 & -0.3 & 0.4 \\
\hline $\mathrm{Zn}$ & 0.9 & -0.8 & 0.9 & -0.6 & -0.9 & -0.9 & -0.1 & -0.3 & 0.2 & 0.6 \\
\hline $\mathrm{Mn}$ & 0.8 & -0.9 & 0.9 & -0.8 & -0.6 & -0.7 & 0.0 & -0.6 & -0.3 & -0.2 \\
\hline $\mathrm{Mg}$ & 0.9 & -0.8 & 0.9 & -0.7 & -0.8 & -0.9 & -0.1 & -0.5 & 0.5 & 0.8 \\
\hline $\mathrm{Pb}$ & 0.9 & -0.7 & 0.9 & -0.9 & -0.7 & -0.9 & -0.1 & -0.6 & -0.3 & 0.5 \\
\hline $\mathrm{Na}$ & 0.8 & -0.8 & 0.9 & -0.8 & -0.2 & -0.4 & -0.5 & -0.5 & 0.2 & -0.3 \\
\hline
\end{tabular}

Overall, sediment contaminant concentration is found to correlate strongly with modal particle size and deposition rate in the wetland and linear wetland, but correlation results are not strong in the swales or pond. In general, greater deposition and smaller modal particle size are found to correlate to higher sediment contaminant concentration. Modal particle size is strongly correlated (for a few contaminants) to contaminant concentration in the short swale and pond (both assets show strong correlations for $\mathrm{Mg}$, but also for numerous different additional contaminants). Thus, modal particle size is found to have a more widespread strong correlation to sediment contaminant concentrations than deposition rate. This result falls in line with published contamination theory and research, such as Forstner and Wittmann [39].

The long swale shows no strong correlations, suggesting this asset's sediment contaminant concentrations are perhaps driven by more complex factors such as inflow concentration, $\mathrm{d}_{10}$ or $\mathrm{d}_{90}$ particle size, long term deposition, location of the asset within the network, asset design (and potentially unmonitored parameters, such as erosion or vegetation maintenance) rather than any clearly dominant, single, parameter (modal particle size or short term deposition).

\section{Analysis and Discussion}

The field sampling of established SuDS illustrates that deposited sediment shows a variety of contamination levels (from exceedance of the contaminated land threshold to below ecotoxicity). To place this information in context, and to provide a method for SuDS managers to identify the general cause, spatial extent and intensity of sediment contamination, a series of enrichment and contamination index tests have been undertaken and consolidated to form an analysis matrix. This sediment contaminant analysis provides a characterisation of the investigated SuDS deposited sediment contamination levels.

Contamination analysis provides quantification of contaminant change relative to background soil levels analysis [40-42]. Background concentrations, collected from the field sites, provided 
location-specific background soil contaminant levels from which to analyse the investigated SuDS deposited sediment. Calculation of contaminant specific contamination factors (CF) were achieved using the following equation $[41,43,44]$ :

$$
\mathrm{CF}=\frac{\mathrm{M}_{\mathrm{x}}}{\mathrm{M}_{\mathrm{b}}}
$$

where:

$\mathrm{CF}=$ contamination factor (dimensionless)

$\mathrm{M}_{\mathrm{x}}=$ sampled major elements and trace metals concentration

$\mathrm{M}_{\mathrm{b}}=$ background major elements and trace metals concentration

For the purposes of this analysis, the variation in CF of importance is centred around 1. CF values $>1$ illustrate enrichment due to anthropogenic activities (such as land use, traffic use of roads). $\mathrm{CF}$ values $<1$ do not illustrate enrichment relative to local background soils. The average $\mathrm{CF}$ values for the monitored SuDS assets are presented in Table 8.

Table 8. Average Contamination Factors for each SuDS asset and contaminant.

\begin{tabular}{cccccc}
\hline \multirow{2}{*}{ Contaminant } & \multicolumn{5}{c}{ Contamination Factor } \\
\cline { 2 - 6 } & Wetland & Linear Wetland & Short Swale & Long Swale & Pond \\
\hline $\mathrm{K}$ & 0.5 & 0.7 & 0.5 & 0.2 & 0.8 \\
$\mathrm{~Pb}$ & 20.7 & 109.9 & 25.8 & 5.2 & 40.9 \\
$\mathrm{Fe}$ & 2.2 & 10.0 & 3.0 & 1.0 & 2.9 \\
$\mathrm{Cd}$ & 0.2 & 0.4 & 0.0 & 0.0 & 7.1 \\
$\mathrm{Cr}$ & 1.5 & 5.0 & 0.7 & 0.2 & 1.5 \\
$\mathrm{Mn}$ & 5.5 & 70.9 & 19.7 & 4.5 & 6.3 \\
$\mathrm{Mg}$ & 1.3 & 3.0 & 0.8 & 0.3 & 2.1 \\
$\mathrm{Al}$ & 0.7 & 3.6 & 1.0 & 0.2 & 1.0 \\
$\mathrm{Zn}$ & 61.1 & 162.4 & 13.9 & 8.1 & 14.5 \\
$\mathrm{Ca}$ & 2.5 & 4.7 & 1.0 & 0.7 & 6.8 \\
$\mathrm{Na}$ & 1.5 & 1.5 & 0.6 & 0.9 & 0.3 \\
$\mathrm{Ba}$ & 1.8 & 8.6 & 2.0 & 0.7 & 2.3 \\
$\mathrm{Cu}$ & 15.3 & 52.2 & 6.4 & 2.4 & 4.9 \\
$\mathrm{Ni}$ & 1.5 & 4.7 & 0.9 & 0.4 & 2.2 \\
$\mathrm{Sn}$ & 11.6 & 59.5 & 17.6 & 0.1 & 10.7 \\
$\mathrm{P}$ & 2.5 & 12.5 & 2.2 & 0.7 & 1.5 \\
\hline
\end{tabular}

Key urban contaminants illustrating enrichment relative to background soil concentrations within the monitored $\mathrm{SuDS}$ are $\mathrm{Zn}, \mathrm{Pb}, \mathrm{Mn}, \mathrm{Cu}$ and $\mathrm{Sn}$; primarily vehicle residuals (from engine wear, combustion, tyre and break material wear), urban road dust, urban waste and industrial emissions or processes $[17,45,46]$. High enrichment values of a contaminant may occur as a result of greater detainment of the contaminant within the specific SuDS asset, the enrichment of sediment by that contaminant due to a phyto- or chemical processes within the asset, or the lack or limited remediation of the contaminant by the specific SuDS asset.

All assets illustrate $\mathrm{Zn}$ and $\mathrm{Pb}$ to be the highest two enriched contaminants. $\mathrm{Mn}$ and $\mathrm{Cu}$ are within the seven most enriched contaminants for all SuDS assets monitored. Cd is the least-enriched contaminant within all monitored SuDS except the pond (where Na shows the smallest average enrichment) and $\mathrm{K}$ has a CF value of less than 2 for all SuDS assets. The long swale clearly illustrates the lowest overall enrichment, with only the four contaminants $(\mathrm{Zn}, \mathrm{Pb}, \mathrm{Mn}$ and $\mathrm{Cu}$ ) illustrating an $\mathrm{CF}$ value of greater than 2 .

CF analysis was extended to consider the intensity of sediment enrichment. Geoaccumulation index (Igeo) analysis provides a characterisation or classification of sediment contamination relative to the background soil levels (relative enrichment rather than comparison to contaminated land 
or ecotoxicity threshold levels). Igeo utilises a scale to access contamination levels as defined by Muller [45]. The scale classifies sediment contamination as uncontaminated (Igeo $\leq 0$ ) to extremely contaminated (Igeo < 5), with no upper or lower limit on possible Igeo values. While CF analysis identifies whether a sediment contaminant is elevated above background levels (and thus potentially anthropogenic enriched), Igeo values indicate the level of contamination relative to background level rather than guideline threshold levels. This quantifies the extent of contaminant concentration increase relative to background soil levels. Igeo scale results were calculated for each of the sediment samples and SuDS assets using the following equation [41,47,48]:

$$
\text { Igeo }=\log _{2} \frac{C_{n}}{1.5 B_{n}}
$$

where:

$\mathrm{I}_{\text {geo }}=$ geoaccumulation index

$C_{n}=$ concentration of the element in the (enriched) samples

$\mathrm{B}_{\mathrm{n}}=$ background concentration of the element

Table 9 summarises the overall Igeo contamination level in each monitored SuDS asset relative to the Muller [47] scale. Igeo results suggest $\mathrm{Sn}, \mathrm{Mn}, \mathrm{Zn}, \mathrm{Cu}, \mathrm{Ba}, \mathrm{Sn}$ and $\mathrm{P}$ to reach contamination levels (relative to background soils concentrations) while the remaining contaminants' enrichment is generally below contamination status according to the Igeo contamination scale. The linear wetland deposited sediment is found to illustrate moderate to extreme contamination for the greatest number of contaminants $(\mathrm{Zn}>\mathrm{Cu}>\mathrm{Mn}, \mathrm{Pb}>\mathrm{Ba}>\mathrm{Sn}>\mathrm{P})$. The linear wetland, long swale and pond show multiple contaminants concentration to increase along the flow path, while enrichment is greater closer to the upstream extent/inlet for the wetland and short swale (with exception of K).

Table 9. Igeo values and trend summary for monitored SuDS assets.

\begin{tabular}{|c|c|c|c|c|c|c|}
\hline & Wetland & Linear Wetland & Short Swale & Long Swale & Pond & Contamination Classification Scale \\
\hline $\mathrm{K}$ & $0-1$ & $0-1$ & $0-1$ & $0-1$ & $0-1$ & uncontaminated \\
\hline $\mathrm{Pb}$ & $<0$ & $5+(<15)$ & $<0$ & $<0$ & $<0$ & moderately uncontaminated \\
\hline $\mathrm{Fe}$ & $0-1$ & $0-1$ & $0-1$ & $0-1$ & $0-1$ & moderately contaminated \\
\hline $\mathrm{Cd}$ & $<0$ & $<0$ & $<0$ & $<0$ & $<0$ & $\begin{array}{l}\text { moderate-strongly } \\
\text { contaminated }\end{array}$ \\
\hline $\mathrm{Cr}$ & $<0$ & $<1$ & $<0$ & $<0$ & $<0$ & strongly contaminated \\
\hline $\mathrm{Mn}$ & $0-3$ & $5+(<15)$ & $5+(<10)$ & $<1$ & $\begin{array}{c}5+ \\
(<15)\end{array}$ & $\begin{array}{l}\text { strongly-extremely } \\
\text { contaminated }\end{array}$ \\
\hline $\mathrm{Mg}$ & $0-1$ & $0-1$ & $0-1$ & $0-1$ & $0-1$ & extremely contaminated \\
\hline $\mathrm{Al}$ & $0-1$ & $0-1$ & $0-1$ & $0-1$ & $0-1$ & \\
\hline $\mathrm{Zn}$ & $5+(<25)$ & $5+(<35)$ & $<1$ & $<0$ & $0-2$ & \\
\hline $\mathrm{Ca}$ & $0-1$ & $0-1$ & $0-1$ & $0-1$ & $0-1$ & \\
\hline $\mathrm{Na}$ & $0-1$ & $0-1$ & $0-1$ & $0-1$ & $0-1$ & \\
\hline Ва & $<0$ & $4-5$ & $<0$ & $<0$ & $0-3$ & \\
\hline $\mathrm{Cu}$ & $<0$ & $5+(<20)$ & $<0$ & $<0$ & $<0$ & \\
\hline $\mathrm{Ni}$ & $<0$ & $<0$ & $<0$ & $<0$ & $<0$ & \\
\hline Sn & $0-2$ & $1-3$ & $0-2$ & $<0$ & $0-2$ & \\
\hline $\mathrm{P}$ & $0-1$ & $1-2$ & $0-1$ & $0-1$ & $0-1$ & \\
\hline
\end{tabular}

Note: green shading illustrates declining trends through the SuDS asset, red shading identifies the increasing sediment contamination along the asset flow path. Unshaded values show negligible change in sediment contamination between inlet and outlet. The Igeo values $(0$ to +5$)$ are classified using the Muller scale [47].

No obvious visible consistency or trend in sediment contamination occurs for any specific contaminant. Contamination levels may be influenced by or change due to asset design, maintenance, flow characteristics, source limitations of phytoremediation processes. Average Igeo values generally indicate sediment to be uncontaminated to moderately contaminated (Igeo $\leq 2$ ) relative to background soil levels. It is noted that average Igeo analysis does not indicate the occurrence of contaminant hot spots in the monitored SuDS. 
The analysis of SuDS deposited sediment contamination using contaminated land threshold, CF and Igeo analysis was collated to form a simple matrix. The matrix can be used to help identify what contaminants may be of concern within the SuDS assets, whether the elevated sediment contaminant concentrations occur due to background soil levels or anthropogenic activities and whether sediment is contaminated throughout the SuDS asset or in hot spot locations. This matrix is presented in Figure 5.

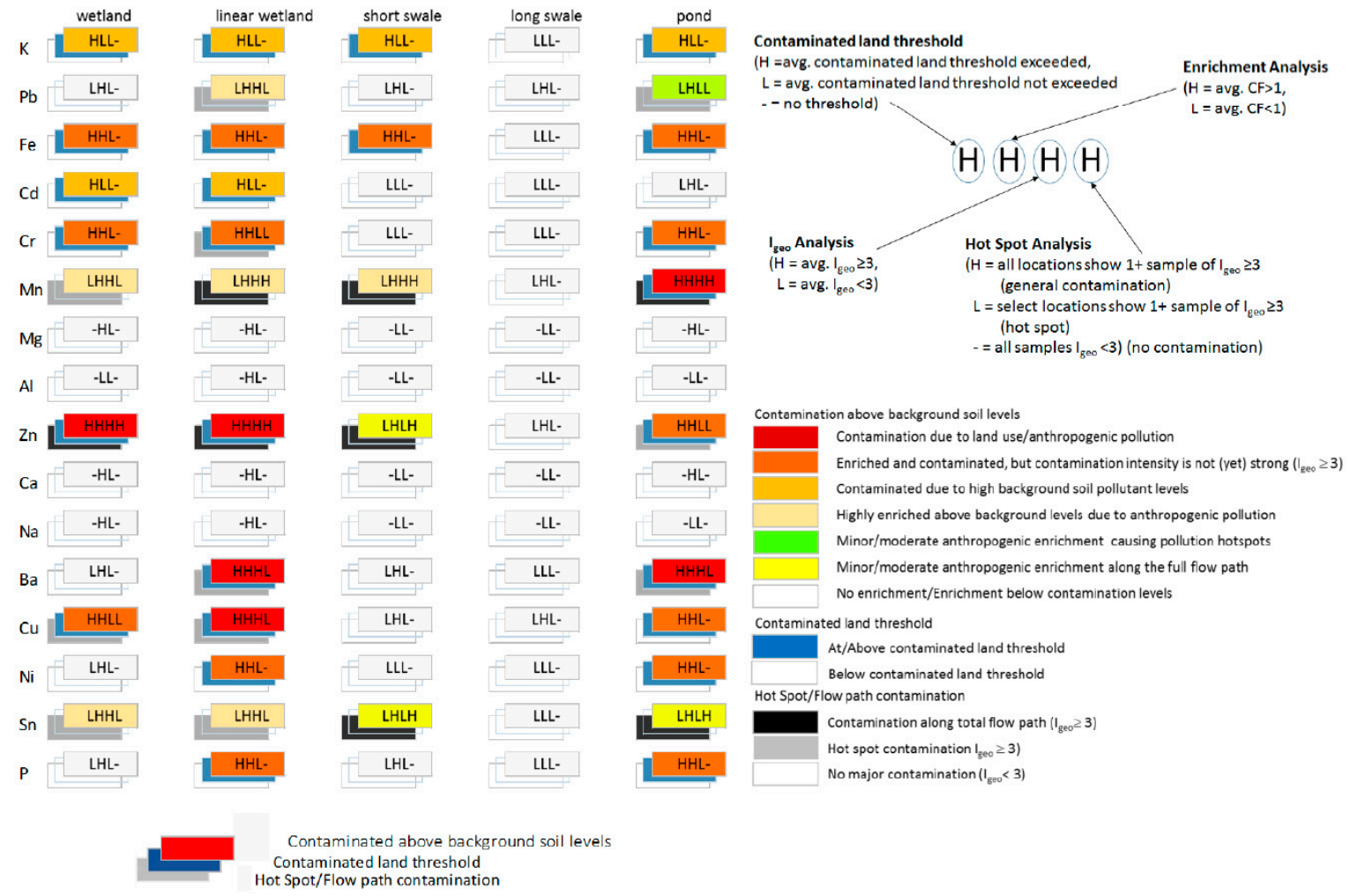

Figure 5. Sediment contamination matrix. The matrix is comprised of three layers of colour indicators, illustrating the alphabetic contamination matrix code (e.g., $\mathrm{HHHH}$, as illustrated to the top right of the matrix).

If the first three components of the alphabetical code are considered, a description of how contaminated and an indication on the source of the contamination can be created (the fourth letter describing the location of the contamination). These can be listed as:

- $\mathrm{HHH}-$ High sediment contamination, high $\mathrm{CF}$, high Igeo = contaminant concentration is occurring due (in part) to urban land use and urban activities rather than background soil influence. SuDS bioremediation has not decreased contaminant levels to below contaminated threshold levels (e.g., linear wetland $\mathrm{Cu}$; wetland and linear wetland $\mathrm{Zn}$; linear wetland and pond Ba; pond Mn).

- HHL-High sediment contamination, high CF, low Igeo = elevated contaminant levels are primarily due to urban influence. The level of contamination is high (above contaminated threshold levels), but the difference between background levels and contaminated threshold levels is small enough to illustrate low Igeo values (i.e., the amount of contaminant enrichment relative to background levels is smaller than in HHH. SuDS bioremediation has not decreased contaminant levels to below contaminated threshold levels (e.g., wetland, linear wetland and pond $\mathrm{Cr}$; wetland, linear wetland, short swale and pond Fe). 
- HLH-High sediment contamination, low CF, high Igeo = contaminant levels are primarily due to background soil contaminant levels, and SuDS remediation measures have not brought sediment contaminant levels down below contaminated threshold levels.

- HLL-High sediment contamination, low CF, low Igeo = contaminant levels are possibly driven by a process within the SuDS asset, such as adsorption or $\mathrm{pH}$ increase, resulting in localised sediment enrichment and urban land use. SuDS remediation measures have not brought sediment contaminant levels down below contaminated threshold levels (e.g., wetland K).

- LHH-Low sediment contamination, high CF, high Igeo = background soil contaminant concentrations are resulting in noticeably increased sediment contaminant concentrations, but not to the extent of specified contaminated threshold levels. SuDS remediation measures may be acting to bring down sediment contaminant levels to below contaminated threshold levels (e.g., wetland, linear wetland and short swale $\mathrm{Mn}$ ).

- LLH-Low sediment contamination, low CF, high Igeo = there is noticeable contamination of the deposited sediment due to urban land use and activities and background soil influence, but not to the extent of surpassing the contaminated threshold levels. SuDS remediation measures may be acting to bring down sediment contaminant levels to below contaminated threshold levels.

- LHL-Low sediment contamination, high CF, low Igeo = deposited contaminant levels are noticeably increased due to urban land use and urban activities, but not to the extent to threshold contaminated soil status or at such a rate to be identified as contaminated on the Igeo scale. SuDS remediation measures may be acting to bring down sediment contaminant levels to below contaminated threshold levels (e.g., wetland and pond $\mathrm{Pb}$; short and long swale $\mathrm{Zn}$ ).

- LLL-Low sediment contamination, low CF, low Igeo = neither background soils or urban influences are resulting in elevated contaminant levels. SuDS remediation measures may be acting to bring down sediment contaminant levels to below contaminated threshold levels (e.g., short and long swale $\mathrm{Cd}$, $\mathrm{Ni}$ and $\mathrm{Cr}$ ).

Figure 5 suggests that for certain contaminants, such as $\mathrm{Zn}$ (HHHH in Figure 5) in the linear wetland, deposited sediment contaminant concentrations are elevated primarily due to urban land use, and that natural remediation measures of the linear wetland have not decreased the contaminant levels to below contaminated threshold levels along any part of the SuDS asset. However, for contaminants such as Mn and Sn in the wetland and linear wetland (LHHL and LHHH in Figure 5), there is (hot spot: $\mathrm{Mn}$ and Sn in wetland, Sn in linear wetland) enrichment above background soil levels, potentially due to urban land use and activities, but that the overall contaminant concentration is below contaminated threshold levels (due to SuDS remediation and/or the level of enrichment occurring).

Figure 5 sediment contaminant analysis illustrates that $\mathrm{HHH}(\mathrm{H} / \mathrm{L})$ and $\mathrm{HHL}(\mathrm{H} / \mathrm{L})$ (no HLH(H/L) values are found in the monitored SuDS) present the greatest contamination risk, thus indicating contaminants and contaminant levels of concern. $\mathrm{HHH}(\mathrm{H} / \mathrm{L})$ suggests sediment contamination which is unsuccessfully treated in the asset or network (treatment train). The linear wetland is therefore inefficient in treating $\mathrm{Zn}, \mathrm{Ba}$ and $\mathrm{Cu}$ sediment contaminants. Similarly, HHL(H/L) indicates contaminants of concern, suggesting poor SuDS performance and possible localised high background or deposited sediment contaminant levels. The short swale, for example, is therefore potentially illustrating poor performance for Fe.

Consideration of the fourth element of the matrix code (from the Hot Spot/Flow path contamination matrix layer) identifies contaminants of general concern and contaminants of concern at hot spots within the SuDS assets. Contaminants of general concern show an average contaminant concentration at or above the contaminated land threshold and an $\mathrm{HHH}(\mathrm{H} / \mathrm{L}), \mathrm{HHLH}$ (and $\mathrm{LHH}(\mathrm{H} / \mathrm{L})$ ) characterisation in Figure 5. Thus, for the wetland $\mathrm{Zn}$ is a contaminant of significant concern across the whole SuDS asset, while $\mathrm{Cu}$ is of concern at hot spot locations. Similarly, the linear wetland illustrates $\mathrm{Zn}$ to be of significant concern across the whole asset, Ba and $\mathrm{Cu}$ to be of significant concern at hot spot locations. Contaminants such as $\mathrm{Sn}$ in both wetland and linear wetland may be of moderate 
concern, with high Igeo contamination indication across the whole SuDS asset potentially rising to contaminated land status. Contaminants such as $\mathrm{Sn}$ and $\mathrm{Zn}$ in the short swale indicate areas of high sediment enrichment at hot spot locations that may need future monitoring to ensure contamination (relative to the contaminated land threshold and average Igeo) does not occur.

The simple matrix presented in Figure 5 provides a method of unravelling SuDS sediment contaminant results to identify the location, possible cause and severity of sediment contamination within monitored SuDS assets. The matrix also provides an insight into the sediment contamination levels of several established SuDS assets for a range of urban contaminants. As illustrated in Figure 5, the monitored SuDS assets show a range of contamination and enrichment levels, both as generalised contamination across the SuDS asset (e.g., $\mathrm{Zn}$ in the wetland) and as hot spot contamination occurrence (e.g., $\mathrm{Cu}$ in the linear wetland). The matrix helps clarify which contaminants are of concern or may be of concern in the future in each SuDS asset.

\section{Conclusions}

Analysis of sediment deposition in established investigated SuDS assets has provided an enrichment and contamination dataset to help identify the existing and potential contamination within the monitored established SuDS assets. Comparison of deposited sediment contaminant concentrations to published contaminated land thresholds illustrates that, within the monitored SuDS, there are several assets that show contaminant concentrations above their relevant contaminated land thresholds. No consistent trend is visually evident in contaminant concentrations within the SuDS assets. CF analysis has identified contaminants, such as K, that illustrate contamination due to high background soil levels rather than urban land use. A simple matrix has been compiled using contaminated land threshold, CF and Igeo analysis to help identify contaminants of concern in the monitored SuDS. This matrix illustrates whether enrichment or contamination occurs across the whole SuDS asset or in hot spots within the assets and if the cause of contamination is from background soils and/or urban land use. The matrix is a step towards a simple method of characterising SuDS sediment major element and trace metal contamination and identifying the extent of deposited sediment contamination within the established SuDS. This information may help inform future maintenance activities and guidance, and assist in advancing design guidelines to incorporate removal of or provision for polluted sediment deposition hot spots within SuDS for water quality improvement purposes.

Acknowledgments: This study is supported by the Engineering and Physical Sciences Research Council (EP/K013661/1 and EP/P003982/1) and the Heriot-Watt University School of the Built Environment. It has been completed as part of the EPSRC Blue-Green Cities Consortium project. The Scottish Universities Environmental Research Centre has provided significant support. The associated metadata/data presented in this research can be accessed using the following doi:10.17639/nott.317.

Author Contributions: Deonie Allen, as the primary author and investigator of this research, undertook the field and laboratory analysis activities of this project; Scott Arthur and Heather Haynes contributed valuable analysis, manuscript and internal review of this research.

Conflicts of Interest: The authors declare no conflict of interest.

\section{References}

1. Woods Ballard, B.; Wilson, S.; Udale-Clarke, H.; Illman, S.; Scott, T.; Ashley, R.; Kellagher, R. The SuDS Manual (C697); CIRIA: London, UK, 2015.

2. Water by Design (2006) Technical Design Guidelines for South East Queensland, Healthy Waterways. Available online: http://healthywaterways.org/u/lib/mob/20151210164506_9581d6262ed405324/2006_ wsudtechdesignguidelines-4mb.pdf (accessed on 5 January 2017).

3. Allen, D.; Olive, V.; Arthur, S.; Haynes, H. Urban sediment transport through an established vegetated swale: Long term treatment efficiencies and deposition. Water 2015, 7, 1046-1067. [CrossRef]

4. Allen, D.; Arthur, S.; Hanes, H.; Olive, V. Multiple rainfall event pollution transport by sustainable drainage systems: The fate of fine sediment pollution. Int. J. Environ. Sci. Technol. 2016, 1-14. [CrossRef] 
5. Jones, A.; Stovin, V.; Guymer, I.; Gaskell, P.; Maltby, L. Modelling temporal variations in the sediment concentrations in highway runoff. In Proceedings of the 11th International Conference on Urban Drainage, Edinburgh, UK, 31 August-5 September 2008.

6. DalCorso, G.S.; Farinati, S.; Maistri, S.; Furini, A. How plants cope with cadmium: Staking all on metabolism and gene expression. J. Integr. Plant Biol. 2008, 50, 1268-1280. [CrossRef] [PubMed]

7. Peng, J.; Song, Y.; Cui, X.; Qui, G. The remediation of heavy metals contaminated sediment. J. Hazard. Mater. 2009, 161, 633-640. [CrossRef] [PubMed]

8. Juwarkar, A.; Yadav, S. Bioaccumulation and biotransformation of heavy metals. In Bioremediation Technology: Recent Advances; Fulekar, M.H., Ed.; Springer: Dordrecht, The Netherlands, 2010; pp. 226-284.

9. Roberts, D.A. Causes and ecological effects of resuspended contaminated sediment (RCS) in marina environments. Environ. Int. 2012, 40, 230-243. [CrossRef] [PubMed]

10. Fleeger, J.W.; Carman, K.R.; Nisbet, R.M. Indirect effects of contaminants in aquatic ecosystems. Sci. Total Environ. 2003, 317, 207-233. [CrossRef]

11. Havens, K.E. An experimental comparison of the effects of two chemical stressors on a freshwater zooplankton assemblage. Environ. Pollut. 1994, 84, 245-251. [CrossRef]

12. Havens, K.E. Structural and functional responses to a freshwater plankton community to acute copper stress. Environ. Pollut. 1994, 86, 259-266. [CrossRef]

13. Forrow, D.M.; Maltby, L. Toward a mechanistic understanding in contaminant-induced changes in detritus processing in streams: Direct and indirect effects on detritivore feeding. Environ. Toxicol. Chem. 2000, 19, 2100-2106. [CrossRef]

14. Heal, K.; Hepburn, D.; Lunn, R. Sediment management in sustainable urban drainage system ponds. Water Sci. Technol. 2006, 53, 216-227. [CrossRef]

15. Environmental Protection Act 1990, UK. Available online: http://www.legislation.gov.uk/ukpga/1990/43 (accessed on 16 February 2017).

16. DERM. Urban Stormwater Quality Planning Guidelines; Department of Environment and Resource Management, Queensland Government: Brisbane, Australia, 2010.

17. Zanders, J.M. Road sediment: Characterisation and implications for performance of vegetated strips for treating road runoff. Sci. Total Environ. 2005, 399, 41-47. [CrossRef] [PubMed]

18. Kayhanian, M.; McKenzie, E.R.; Leatherbarrow, J.E.; Yound, T.M. Characteristics of road sediment fractionated particles captured from paved surfaces, surface runoff and detention basins. Sci. Total Environ. 2012, 439, 172-186. [CrossRef] [PubMed]

19. Droppo, I.; Irvine, K.N.; Jaskot, C. Flocculation/Aggregation of Cohesive Sediments in the Urban Continuum: Implications for Stormwater Management. Environ. Technol. 2010, 23, 27-41. [CrossRef] [PubMed]

20. Van Rijn, L.C. Principles of Sediment Transport Tin Rivers, Estuaries and Coastal Seas; Aqua Publications: Amsterdam, The Netherlands, 1993.

21. Lawler, D.M. The measurement of river ban erosion and lateral channel change: A review. Earth Surf. Process. Landf. 2006, 18, 777-821. [CrossRef]

22. International Atomic Energy Agency. Collection and Preparation of Bottom Sediment Samples for Analysis or Radionuclides and Trace Elements; IAEA: Vienna, Austria, 2003; ISBN 92-0-109003-X.

23. Fraley, L. Methods of Measuring Fluvial Sediment, Centre for Urban Environmental Research and Education; University of Maryland: Baltimore, MD, USA, 2004.

24. Nham, T. Monitoring Heavy Metals by ICP-OES for Compliance with RoHS an WEEE Directives; Agilent Technologies, Inc.: Santa Clara, CA, USA, 2010; Available online: http://cn.agilent.com/cs/library/applications/io-040. pdf (accessed on 1 November 2010).

25. Hseu, Z.Y. Evaluating heavy metal contents in nine composts using four digestion methods. Bioresour. Technol. 2004, 95, 53-59. [CrossRef] [PubMed]

26. Etzler, F.; Deanne, R. Particle size analysis: A comparison of various methods II. Part. Part. Syst. Charact. 1997, 14, 278-282. [CrossRef]

27. Ramaswaamy, V.; Rao, P.S. Grain size analysis of sediment from the northern Andaman Sea: Comparison of laser diffraction and sieve-pipette techniques. J. Coast. Res. 2006, 22, 1000-1009. [CrossRef]

28. Australian and New Zealand Environment and Conservation Council and Agriculture and Resource Management Council of Australia and New Zealand. Australian and New Zealand Guidelines for Fresh and Marine Water Quality; ANZECC \& ARMCANZ: Artarmon, NSW, Austria, 2000. 
29. DEC. Assessment Levels for Soil, Sediment and Water; Department of Environment and Conservation: Perth, Western Australia, 2010.

30. Ontario Ministry of Environment. Guidelines for the Protection and Management of Aquatic Sediment Quality in Ontario; Ontario Ministry of the Environment: Toronto, ON, Canada, 1993.

31. Inter Departmental Committee for the Redevelopment of Contaminated Land (ICRCL). Guidance on the Assessment and Redevelopment of Contaminated Land, Guidance Note 59-83; Department of the Environment: London, UK, 1987.

32. US EPA Regional Screening Levels (RSLs)—Generic Tables (May 2016), US Environmental Protection Agency. Available online: www.oehha.ca.gov/risk/chemicalDB/index.asp (accessed on 5 September 2016).

33. Kopittke, P.M.; Menzies, N.W. Effect of $\mathrm{Cu}$ toxicity on the growth of Cowpea, (Vigna unguiculata). Plant Soil 2006, 279, 287-296. [CrossRef]

34. Horneck, D.A.; Sullivan, D.M.; Owen, J.S.; Hart, J.M. Soil Test Interpretation Guide; Oregon State University, Extension Service: Corvallis, OR, USA, 2011.

35. Paterson, E.; Owen, J. Report on the Analysis of Crushed Granite Sample for Elemental Concentration, Aqueous Extractable Elements, and $C$ and $N$, Total $C$ and $N$, Extractable Nitrate, Loss on Ignition, Particle size Distribution and Ecotoxicity; Report for Cloburn Quarry Company Ltd.: Aberdeen, UK, 2011.

36. Heal, K. SuDS ponds in Scotland-Performance outcomes to date. In Proceedings of the Standing Conference on Stormwater Source Control, Coventry, UK, 19 September 2000.

37. Heal, K.; Drain, S. Sedimentation and sediment quality in sustainable urban drainage systems. In Proceedings of the 2nd National Conference on Sustainable Drainage, Coventry, UK, 23-24 June 2003.

38. Napier, C.; Jefferies, C.; Heal, K.; Fogg, P.; D'Arcy, B.; Clarke, R. Evidence of traffic-related pollutant control in soil-based Sustainable Urban Drainage Systems. In Proceedings of the 11th International Conference on Urban Drainage, Edinburgh, Scotland, UK, 31 August-5 September 2008.

39. Forstner, U.; Wittmann, G.T.W. Metal Pollution in the Aquatic Environment; Springer-Verlag: Berlin/Heidelberg, Germany; New York, NY, USA, 1979.

40. Shafie, N.; Aris, A.; Sakaria, M.; Lim, W.; Isa, N. Application of geoaccumulation index and enrichment factors or the assessment of heavy metal. J. Environ. Sci. Health Part A 2013, 48, 182-190. [CrossRef] [PubMed]

41. Abrahim, G.; Parker, R. Assessment of heavy metal enrichment factors and the degree of contamination in marine sediments from Tamaki Estuary, Auckland, New Zealand. Environ. Monit. Assess. 2008, 136, 227-238. [CrossRef] [PubMed]

42. Loska, K.; Cebula, J.; Pelczar, J.; Wiechuła, D.; Kwapuliński, J. Use of enrichment, and contamination factors together with geoaccumulation indexes to evaluate the content of $\mathrm{Cd}, \mathrm{Cu}$, and $\mathrm{Ni}$ in the Rybnik water reservoir in Poland. Water Air Soil Pollut. 1997, 93, 347-365. [CrossRef]

43. Zoller, W.H.; Gladney, E.S.; Duce, R.A. Atmospheric concentrations and sources of trace metals at the South Pole. Science 1974, 183, 199-201. [CrossRef] [PubMed]

44. Hurley, R.; Rothwell, J.; Woodward, J. A catchment-wide assessment of bed sediment metal concentrations in the first industrial city. In Proceedings of the EGU General Assembly Conference Abstracts, Vienna, Austria, 17-22 April 2016; Volume 18, p. 3095.

45. Van Meter, P.; Mahler, B. The contribution of particles washed from rooftops to contaminant loading to urban streams. Chemosphere 2003, 52, 1727-1741. [CrossRef]

46. Hubbard, J.A. Using sediment particle size class analysis to better understand urban land use effects. Int. J. Appl. Sci. Technol. 2012, 2, 12-27.

47. Muller, G. Index of geoaccumulation in sediments of the Rhine River. Geol. J. 1981, 2, 109-180.

48. Ghrefat, H.A.; Abu-Rukah, Y.; Rosen, M.A. Application of geoaccumulation index and enrichment factor for assessing metal contamination in the sediments of Kafrain Dam, Jordan. Environ. Monit. Assess. 2011, 178, 95-109. [CrossRef] [PubMed]

(C) 2017 by the authors. Licensee MDPI, Basel, Switzerland. This article is an open access article distributed under the terms and conditions of the Creative Commons Attribution (CC BY) license (http:/ / creativecommons.org/licenses/by/4.0/). 